Regular training and adequate nutrition are key factors in modulating exercise performance: Optimal performance requires a healthy diet adapted to the specific demands of the individual athlete's training and competition. Research has shown an impact of dietary intervention on the modulation of the skeletal muscle adaptive response to prolonged exercise training. Proper nutritional coaching should therefore not be restricted to the competitive events, but needs to be applied throughout both training and competition, each with its specific requirements regarding nutrient provision. Proper nutritional counseling will thus improve exercise training efficiency and ultimately increase performance capacity. Moreover, dietary counseling to modulate training efficiency is also relevant to the general public and the more frail clinically compromised patient groups.

This book provides a solid scientific basis to help the reader define key targets for future interventions and develop new insights into the complex interaction between nutrition and exercise.

Nestlé Nutrition Institute Workshop Series, Vol. 75

Nutritional Coaching Strategy

to Modulate Training Efficiency

Editors: Tipton, K.D. (Stirling);

van Loon, L.J.C. (Maastricht)

XIV + 146 p., 16 fig., 13 tab., 2013

CHF 50.- / EUR 42.- / USD 59.00 (hard cover)

CHF 60.- / EUR 50.- / USD 71.00 (online)

Online versions for institutional purchase

Prices subject to change

EUR price for Germany, USD price for USA only

ISBN 978-3-318-02332-9 (hard cover)

e-ISBN 978-3-318-02333-6

Fields of Interest: Nutrition; Sports Medicine; Metabolism

Diet adaptation and athletic performance what is the connection?

Nestlé Nutrition Institute Workshop Series, Vol. 75

\title{
Nutritional Coaching Strategy to Modulate Training Efficiency
}

Editors

Kevin D. Tipton
Luc J.C. van Loon

\section{Contents}

Preface

Foreword

Contributors

Nutritional Strategies to Modulate the Adaptive Response to Endurance Training: Hawley, J.A.

Practical Considerations for Bicarbonate Loading and Sports Performance: Burke, L.M.

Influence of Dietary Nitrate Supplementation on Exercise Tolerance and Performance:

Jones, A.M.; Vanhatalo, A.; Bailey, S.J.

Nutritional Strategies to Support Adaptation to High-Intensity Interval Training in Team Sports: Gibala, M.J.

Dietary Strategies to Attenuate Muscle Loss during Recovery from Injury: Tipton, K.D.

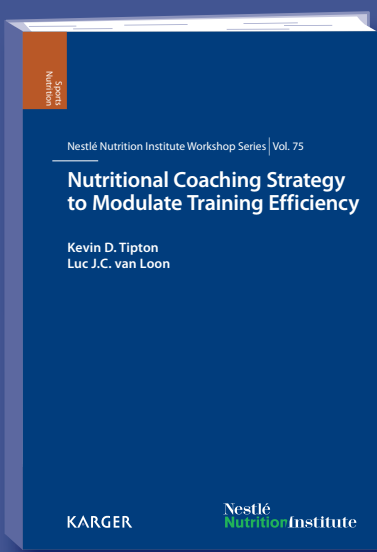

The New Carbohydrate Intake Recommendations: Jeukendrup, A.

Role of Dietary Protein in Post-Exercise Muscle Reconditioning: van Loon, L.J.C.

Nutritional Support to Maintain Proper Immune Status during Intense Training: Gleeson, $M$.

Use of ß-Alanine as an Ergogenic Aid: Derave, $W$.

Vitamin D Supplementation in Athletes: Larson-Meyer, $E$.

Weight Management in the Performance Athlete: Manore, M.M.

Concluding Remarks: Nutritional Strategies to Support the Adaptive Response to Prolonged Exercise Training: van Loon, L.J.C.; Tipton, K.D. 


\section{Order Form}

\section{Nestlé Nutrition Institute Workshop Series}

Nestlé

NutritionInstitute

ISSN $1664-2147$

e-ISSN 1664-2155

In 2011, the two book series 'Nestlé Nutrition Workshop Series: Pediatric Program' and 'Nestlé Nutrition Workshop Series: Clinical \& Performance Program' have been merged to form the 'Nestlé Nutrition Institute Workshop Series'. One of the major components of this series is the organization of workshops and the publication of the proceedings. Each workshop focuses on the latest findings, the controversies and further research needs concerning various topics in nutrition.

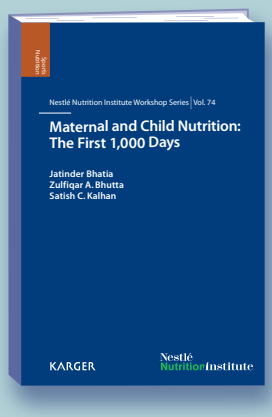

\section{Vol. 74}

Maternal and Child Nutrition: The First 1,000 Days

Editors: Bhatia, J. (Augusta, Ga.); Bhutta, Z.A. (Karachi);

Kalhan, S.C. (Cleveland, Ohio)

hard cover, 2013

CHF 50.- / EUR 42.- / USD 59.00 (hard cover)

CHF 60.- / EUR 50.- / USD 71.00 (online)

ISBN 978-3-318-02387-9 (hard cover)

e-ISBN 978-3-318-02388-6
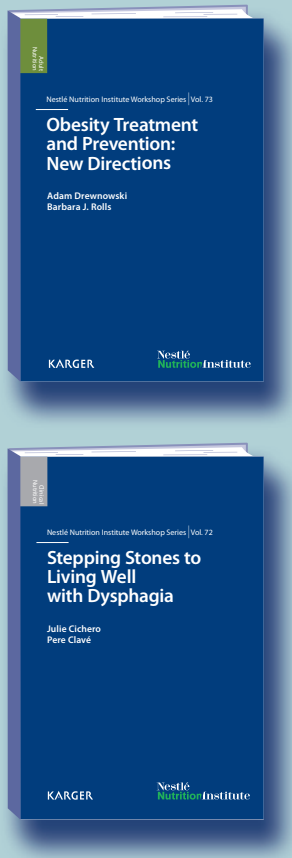

Vol. 73

Obesity Treatment and Prevention: New Directions

Editors: Drewnowski, A. (Seattle, Wash.);

Rolls, B.J. (University Park, Pa.)

XVI +150 p., 12 fig., 8 tab., hard cover, 2012

CHF 50.- / EUR 42.- / USD 59.00 (hard cover)

CHF 60. - / EUR 50. - / USD 71.00 (online)

ISBN 978-3-318-02115-8 (hard cover)

e-ISBN 978-3-318-02116-5

Vol. 72

Stepping Stones to Living Well with Dysphagia

Editors: Cichero, J. (Brisbane, Qld.); Clavé, P. (Barcelona)

XVI + 138 p., 17 fig., 19 tab., hard cover, 2012

CHF 50.- / EUR 42.- / USD 59.00 (hard cover)

CHF 60.- / EUR 50.- / USD 71.00 (online)

ISBN 978-3-318-02113-4 (hard cover)

e-ISBN 978-3-318-02114-1

Online versions are designed for institutional purchase

Prices subject to change

EUR price for Germany, USD price for USA only
Nestlé Nutrition Institute Workshop Series

Please send

_ copy/ies: Vol. 75: Nutritional Coaching Strategy to Modulate Training Efficiency CHF 50.- / EUR 42.- / USD 59.00

ISBN 978-3-318-02332-9

e-ISBN 978-3-318-02333-6

_ copy/ies

ISBN 978-3-318-

The book series Nestlé Nutrition

Workshop Series on

continuation beginning with vol.

All Karger series are available on continuation. Each new volume will be sent upon publication until order is countermanded.

Postage and handling free with prepayment

For easy ordering or information

about other Karger publications log on to: www.karger.com

Payment

$\bigcirc$ Check enclosed $\bigcirc$ Please bill me

$\bigcirc$ Please charge to my credit card

$\begin{array}{ll}\bigcirc \text { American Express } & \bigcirc \text { Diners } \\ \bigcirc \text { MasterCard } & \bigcirc \text { Visa }\end{array}$

Card No.

Exp. date:

CVV/CVC:

Name/Address:

Date:

Signature:

Orders can be placed at agencies, bookstores, directly with the publisher, or with any Karger distributor.

S. Karger AG, P.O. Box, 4009 Basel (Switzerland) Fax +41 6130612 34, E-Mail orders@karger.com

USA: S. Karger Publishers, Inc., 26 West Avon Road,

P.O. Box 529, Unionville, CT 06085 (USA),

Toll free: +1-800-828-5479

Germany: S. Karger GmbH, 79095 Freiburg

France: Librairie Médi-Sciences, 75007 Paris

Japan: Karger Japan, Inc., Tokyo 105-0012

South East Asia, China and Taiwan:

Karger Regional Office, Kuala Lumpur 50470 (Malaysia)

For details and further representatives

and agencies see www.karger.com/worldwide 